\title{
The Role of Intellectual Capital in the Development of the Competitive Capacities in the Cement Company of "Ain Touta" Algeria
}

\author{
Yahiaoui Naima ${ }^{1}$, Megri Zakia ${ }^{1}$, Yousfat Ali $^{2}$ \\ ${ }^{1}$ Faculty of Economic, Commercial and Management Sciences, Batna University, Batna, Algeria \\ ${ }^{2}$ Faculty of Economic, Commercial and Management Sciences, Ahmed Draia University, Adrar, Algeria \\ Email address: \\ yahiaoui966@gmail.com (Y. Naima),megrizakia@yahoo.fr (M. Zakia), yousfatali@gmail.com (Y. Ali)
}

\section{To cite this article:}

Yahiaoui Naima, Megri Zakia, Yousfat Ali. The Role of Intellectual Capital in the Development of the Competitive Capacities in the Cement Company of "Ain Touta" Algeria. Journal of Investment and Management. Vol. 4, No. 3, 2015, pp. 84-94. doi: 10.11648/j.jim.20150403.12

\begin{abstract}
This study aimed to analyze and testing the relationship between intellectual capital and the development of competitive capacities by adopting a virtual model and a research questionnaire and by testing the validity of hypotheses based on the statistical methods used in the study. The results showed the existence of a relationship between the independent variable which is only the relations capital and the development of the competitive capacities of the direction, and that there is a strong impact between intellectual capital and the development of competitive capacities in the direction. The study showed also that there is no relationship between the independent variables which are human capital and structural capital and the dependent variable which is competitive capacities.
\end{abstract}

Keywords: Intellectual Capital, Competitive Capacities, Cement Company

\section{Introduction}

The data of the past millennium nineties demonstrated the progression of concern with the knowledge and concepts associated with cognitive capital and Information Society. This coincided with the increasing of cognitive, intellectual and mental contents as a logical consequence of the technological development associated with the increase in the proportion and number of intellectual human resources on the one hand, and of business and intensive-knowledge jobs on the other hand.

The competition faced by the organizations became a reality by many changes in their environments; the organizations began to be aware of this competition and has touched the increase of its intensity, as well as the emergence of many new competitors encouraging them to look for strategies and multiple policies through which they can achieve competitive advantage and to reserve it. So, the organizations, in various forms, sought to achieve competitive advantage in the quality of services, the methods of providing them, the means of satisfying the needs of their clients, and the search for best practices that they can apply.

There is no doubt that all organizations have not come to an accurate understanding of the importance of intellectual capital and how to exploit its three dimensions (human capital, structural capital, relations capital). We find that the concern with the individual as competitive advantage has not appeared only in a relatively late times. Today, in the context of knowledge world, the domain is no longer opened to all organizations to enter to the competition and to stay actively involved in the market. So, it has become imperative for organizations to determine their intellectual capital and learn how to turn it into profits or to a strategic situation and competitive advantage, then they must look for intellectual wealth, unexploited creative and innovative skills, abilities and ideas contained in their human resources so that they can invest their higher value through developing and turning them into profits or to better strategic center, or to achieve competitive advantage in these difficult economic conditions.

\section{Study's Problem}

What is the role of intellectual capital in the development of competitive capacities in the cement direction of "Ain Touta"? 


\section{Study's Hypotheses}

\subsection{Principle Hypothesis}

There is a relationship of statistical significance between the availability range of intellectual capital requirements and the development of competitive capacities at the level of significance $\mathrm{a}=0.05$.

\subsection{Secondary Hypotheses}

- There is a relationship of statistical significance between the availability range of human capital requirements and the development of competitive capacities at the level of significance $a=0.05$.

- There is a relationship with statistical significance between the availability range of structural capital requirements and the development of competitive capacities at the level of significance $a=0.05$.

- There is a relationship with statistical significance between the availability range of relations capital requirements and the development of competitive capacities at the level of significance $a=0.05$.

\section{Study's Importance}

The importance of this study is related to the importance of intellectual capital as an important source of corporates profitability and the basic support of competitiveness; Interesting in it by organizations and companies is imposed by the nature of scientific and economic challenges, fast technological developments and pressures.

\section{Study's Objectives}

Since scientific research seeks to achieve general and personal objectives with scientific value and significance, this research aims to the following:

- Shedding light on the nature of intellectual capital and its relationship with competitive advantage.

- Identifying the availability of intellectual capital components in the cement direction.

\section{Study's Methodology}

In order to reach the objective of the research and answer the questions asked in the problem, the inductive method will be adopted: case study method.

Study's Structure

To treat this issue and take its aspects, it is divided into two chapters, one is theoretical and the other is practical:

- Chapter one: the theoretical framework of the relationship between intellectual capital and competitive capacities.

- Chapter two: the study of intellectual capital and its role in raising competitive capacities in the general direction of cement "Ain Touta".

\section{First: Theoretical Framework of the Relationship Between Intellectual Capital and Competitive Capacities}

In the light of the knowledge economy, intangible assets have become the basic support and strategic resource to the organization wealth and prosperity. The success of organizations in the fierce competition environment has become dependent on the value of these assets and their management strategies, due to their active role in the exploitation of staff capacities and skills in reinforcing competitive advantage of the company and creating the value. Researchers have named this: "intellectual capital" term (Stewart \& Thomas, 1997).

\subsection{What is Intellectual Capital?}

The concept of capital has been expanded to cover the entire material, financial, moral, intellectual and cultural potentials of the establishment; this term was borrowed to be used in the field of social sciences and management as what is known by human capital which refers to the overall skills, experiences, education and knowledge accumulated in the human element. After, the continuous development of this term, it has been focused on intellectual capital as one of the most important intangible assets affecting competitive advantage of the establishment.

\subsubsection{The Concept of Intellectual Capital}

Ralph Stayer, manager of Johnsonville company for foods, was the first person that launched the term of "intellectual capital" in 1990 when he said: "In the past, natural resources were the most important national wealth components and the most significant assets of the companies, then capital represented by money and fixed assets became the most important components of companies and society. But now, natural resources, money and fixed assets are replaced by intellectual capital which is the most important component of the national wealth and the most expensive asset of corporates."

Edvinsson (1999) defines intellectual capital as the "intangible assets characterized by the absence of a physical entity, in addition to the uncertainty of future benefits expected of them because of the difficulty in predicting their productive age, which makes it difficult to be measured and evaluated, these assets are among the determinants of competitive capacities of the organization.

Guthrie (2001) points out that intellectual capital is "distinct capabilities enjoyed by a limited number of personnel in the organization, which will enable them to provide intellectual contributions to enable the organization to increase its productivity, and to achieve higher levels of performance compared to similar organizations".

From the above, a general definition of intellectual capital can be drawn as "distinct intellectual capacities and contributions owned by the individuals of the organization which in turn helps them to employ them through its 
programs and regulations to be embodied in excellence services and products for clients."

Curado, Henriques and Bontis (2011) present quite a new attitude to intellectual capital and its nature. Scientists emphasize that nowadays the most important element of intellectual capital is Knowledge Based-View of the firm (KBV). Knowledge is considered to be the main factor for growth of intellectual capital. They also presented a new methodology called MMRIC - Measure, Manage and Report of Intellectual Capital - which encouraged companies to measure, manage, and control their intellectual capital. The methodology allows managers to increase a company's value added with little costs.

Bontis, Richards and Serenko (2011) emphasized the importance of Knowledge Management (KM). Knowledge Management is defined as accumulation, concentration, maintenance, and sustention of intellectual capital. This also depends on the type of the company and on the area the company is working in. Nevertheless, Knowledge Management depends also on the mission and vision of the company and its anticipated goals and tasks.

\subsubsection{The Importance of Intellectual Capital}

The following criteria show the importance of intellectual capital for society and business organizations:

1. The importance of intellectual capital is highlighted as the most important source of profitability and competitive pillar of the establishment; normal intellectual capacities have become one of the most important factors of competitive success and distinction in the knowledge-based world economy; all creations begin with creative ideas, and intellectual base construction process represents a significant commitment for higher direction, the reorganization and the new engineering for various activities and operations.

2. In the light of the knowledge-based economy, intellectual capital has become a strategic resource, a competitive weapon with a powerful force for this economy and the main source of wealth and prosperity.

3. Intellectual capital is an important basis in building smart organizations, through the availability of clever minds that are able to invest the rest of the resources and exploit it for expanding the excellence space for their organizations, because those minds are able to adapt to changing circumstances, and this is the intellectual capital.

4. The importance of intellectual capital is derived from being the most valuable asset in the XXI century in an economy called (knowledge economy) because it represents scientific forces able to introduce essential amendments to everything in their organization business as well as their successive innovations.

\subsection{Elements and Components of Intellectual Capital}

There is no doubt that the determination of elements and components of intellectual capital is one of the fundamental things that helps in its measurement and evaluation, and thus in determining the true value of the business organizations in the modern era. The following is a review of the most important of these categories:

\subsubsection{Brookings Institute Classification}

Brooking Institute (1996) classified intellectual capital into four categories or components:

- Market Assets: include all intangible market-related aspects such as clients, brands and distribution outlets.

- Human Assets: include accumulated experiences, capabilities of innovation and indicators related to the extent of the ability of individuals to perform in certain situations.

- Individual Property Assets: include relations, trade secrets, patents and design rights.

- Infrastructure Assets: include all the elements that determine how the establishment works, such as: the establishment's culture, methods of risk assessment, management methods of the labor force, customer databases and communication systems.

\subsubsection{Stewart, 1997 \& Mayo, 2000 Classification and McElroy 2002 Classification}

According to the above classification, intellectual capital consists of the following elements:

- Structural Capital: it is regulatory capacities of the organization that regulate and satisfy the requirements of clients and contribute to the knowledge transfer and reinforcement through intellectual structural assets represented by information systems, patents, copyrights, and the extent of trademark protection which represents the personality and identity of the organization, gives a benefit to the client and increases his satisfaction, as well as a benefit of the organization to increase its efficiency and effectiveness.

Human capital refers to the value of knowledge, skills and experience held by individual employees in a firm. (Ngah. R\&Abdul Razak. I, 2009).

- Human Capital: it is the basic source to train and individualize people who have mental ability and necessary skills and experiences to find appropriate practical solutions to the requirements and desires of clients because they are the source of innovation and renewal in the organization.

- Relations capital: it refers to relations between the organization and its clients, suppliers and strategic alliances (McElroy, 2002).

It also can be contain Social capital that defines as the network of relationships that individuals have throughout the organization ;such relationships are critical in sharing and leveraging knowledge and in acquiring resources.Social capital also can extend beyond the organizational boundaries to include relationships between the firm and its suppliers,customers, and alliance partners (Lumpkin Eisner.D,2008). 


\section{Bases About Competitive Advantage}

The study of competitive advantage in the organization focuses on the internal factors that make the organization strong or weak; the analysis at the sector level focuses on the interest of the ruling policy on the specific economic domain, the consideration of organizations as independent entities and making comparisons between them. The analysis at the macroeconomic performance level focuses on the study of the factors that lie behind the strength or weakness of the economic performance.

\subsection{Concepts of Competitive Advantage}

Michael Porter (1993) is the most important researcher in the field of strategic management and competitive advantage analysis for organizations. He sees that competitive advantage is not concerned with the state, but with the organization (Porter, 1993). Competitive advantage arises mainly from the value that an organization was able to create for its clients so it can take the form of lower prices than the competitors ones with equal benefits, and proving single benefits in a product to consciously compensate the imposed price increase.

Competitive advantage indicates the areas in which the organization can compete with others in a more effective manner. Thus, it represents a point of strength characterizing the organization from its competitors in one of its production, marketing or financing activities, or with respect to human resources and competencies. Competitive advantage depends on the results of the examination and analysis of all of the internal points of strength and weakness as well as the opportunities and risks surrounding and prevailing in the organization environment compared to its competitors.

Competitive advantage is that strategic concept which reflects the relative and constant competitive position of an organization over its competitors, so that manifests in the form of presenting products or services of single characteristics to which the client is prepared to pay more, or providing products or services which are not less valuable than competitors' products and at lower prices.

The realization of competitive advantage depends on the availability of many elements and on the nature of the interaction and integration between them; the most prominent elements of competitive advantage are the availability of natural resources, capital, technology and human resources.

Evans and Collier (2007) noted that competitive advantage is the ability of company to superiority in the areas of marketing, finance, above all priority which in turn requires an understanding of the general framework of the company through: The senior management must determine the needs and desires of the customer and how to deliver it to the customer through processing chain in order to meet the customer plugged in and handed over the goods or services in a timely manner, as well as to take into account the operational capacity rate.

\subsection{The Degree of Competitive Advantage Durability}

To become a durable advantage, two principle properties are necessary in the distinctive capacities of the establishment; the first one is the "durability" and the other is the "imitability". The durability indicates the rate of depreciation or depletion of the establishment resources or its distinctive capacities; the developed technology may lead to finish the distinctive capacity of an establishment. The imitability refers to the possibility of simulating distinctive capacities or competitive resources of an establishment by competitors.

Many companies resort to reverse engineering which is based on analyzing the contender product to identify its components, attracting the workers of the competitor companies or laying hands on patents. It is easy to imitate essential capacities if they are transparent, transferable and reliable (McGee \& Love, 1999).

- Transparency: It refers to the speed of understanding the relations between the resources and capacities supporting the strategy of a successful establishment. For example, the Company Gillette for shaving kits excels through adopting researches and development in the design of blades and shavers; this technique is difficult to be imitated by competitors.

- Transferability: It refers to the ability of competitors to gather the resources and capacities needed to support the competitive challenge. For example, it is difficult to simulate necessary environmental and climatic conditions for the cultivation of tea in India and Ceylon.

- Reliability: It is the ability of competitors to use counterfeit resources and capacities to emulate the success of competitors. We must admit that the success reflects a certain combination of tangible and intangible resources and abilities that cannot be often imitated and emulated by competitors.

The resources and capacities of the establishment can be expressed through the perspective of durability which is shown in Figure (01).

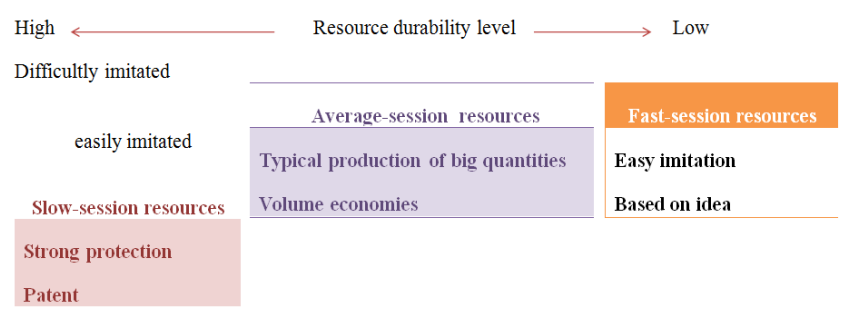

Figure 01. Resource durability perspective (Williams, 1992).

This figure shows that the durability of resources ranges between "low" and "high"; resources with slow-session are durable resources due to their protection through "patents", the geographical area, strong brand or knowledge emanating from the experiences and culture of the establishment's workers. On the other side, there are fast-session resources that are easily imitated.

It is known that organizations seek to achieve the greatest possible productivity of high level of quality and durable renovation of its products, services and all of its divisions due to the ongoing changes in the tastes and needs of customers 
and all of these interactions to achieve excellence.

1. Excellent Competence: The organization is a system for converting inputs to outputs, so we find that the simplest measure of competence is the amount of inputs required to produce given outputs; if the competence rate of the organization's operations increases, the inputs required to produce given outputs decrease, so the cost of the production structure of the organization goes down.

2. Excellent Quality: The achievement of high levels of quality in the products and services by the organization will increase the value of these products and services for their clients, and will enable it to impose a higher price for its products, which leads to realize competitive advantage for the organization and enable it to survive and continue.

3. Excellent Creativity: It refers to all the progress that occurs to the products or services of the organization, its administrative structures, methods and strategies, in the sense that it is achieved through the provision of a new product or the work in a new way which is different from competitors.

4. Renovation is one of the building foundations of competitive advantage that allows to the organization to be distinctive, and thus to impose higher prices or reduce its production costs.

5. Excellent responsiveness to the needs of clients: The organization can achieve competitive advantage through its ability to provide and produce goods and services saturating the needs of its clients better than its competitors. Therefore, there will be harmonization between these goods and services with individual or collective demands. The quality and renovation can be considered complementary aspects of the responsiveness to the needs of the client.

\section{The Relationship Between Intellectual Capital and the Achievement of Competitive Advantage}

As a result of the difficulties faced by organizations in their analysis of these distinctive resources, some people tried to find some theories and analyzes. At this point, we will try to clarify some of them and how to apply them to achieve competitive advantage.

\subsection{Resources-Based Theory}

It is also known as resources-based vision in the strategic management field. Competitive advantage is determined, according to this theory, through the following: distinctive resources, organizational capacities and competencies, technological capabilities, invisible assets represented by knowledge, skills, experiences and human resources, and the axial capacities associated with skills, knowledge, technology management, attitudes and values. This theory gives great attention to the resources and capacities which are available to the organization as a basis to achieve competitive advantage
(Carmeli \&Cohen). It believes that the achievement of competitive advantage by organization depends on the acquisition of strategic resources enjoyed by a set of characteristics and conditions, as well as the capacities of the organization to use these resources.

\subsection{VRIO Framework for Resources Analysis}

Barney (2003) provided a framework (VRIO) for the analysis of each resource of the principle resources of the establishment in terms of its contribution in achieving competitive advantage through having the following characteristics:

- Value: does it add value to clients and provide competitive advantage?

- Scarcity: do competitors have something like it?

- Imitability: is the cost of its imitation high?

- Regulation: Does the regulation of the establishment allow exploiting this resource? Are there available alternatives to this resource?

In case of the answer with "yes" to those questions within VRIO framework for a particular resource, that resource will reflect a point of strength and distinctive ability for the establishment. The evaluation of the importance of these resources contributes to make sure they represent strategic internal factors - that is to say strength and weakness elements that will help to determine the future of the establishment. This can be done by comparing the standards of these resources with the standards of: (1) past performance of the establishment, (2) major competitors of the establishment, (3) industry average as a whole. The resource is a strategic element that must be taken into account when making strategic decisions if it is significantly different from the past, competitors or the industry average.

\section{Chapter two: the Role of Intellectual Capital in the Development of Competitive Capacities of the Cement Company of Ain Touta}

After we determined in the first chapter the theoretical framework of the study's variables which are intellectual capital, the development of competitive capacities and also the nature of the relationship between the two variables, this chapter is an attempt to project what has been theoretically studied on one of the production companies which is the cement company of "Ain Touta".

\section{Designation of the Cement Company "Ain Touta"}

\subsection{Origination of the Cement Company "Ain Touta"}

It is a subsidiary company of the cement complex GICA. It seeks through its activities to satisfy the various needs of the construction sector in terms of the cement. It appeared by 
concluding a contract between the Enterprise of Cement and its Derivatives of the East, in 1983, with the Danish company F.L.S to realize the cement unit "Ain Touta" with collaboration, according to the competence, as the Belgian company competent in the affairs of civil engineering and a company of electricity and mechanical installation works.

The first experience of production was in September $3^{\text {rd }}$, 1986 with production capacity of 1 million tons per year, equivalent to 84,000 tons per month.

\subsection{The Company's Objectives}

The ultimate objective of the company is the financial profit, but there are sub-objectives relating to achieve the required levels of service and quality to win the satisfaction of clients. The company's objectives can be illustrated as follows:

- The work to fill the needs of the market;

- The promotion of the national and international production and providing products with high quality and favorable prices;

- The use of the latest technology.

The company tends, through these objectives, to increase its market share, to flood the market and to raise the company's reputation by satisfying clients and ensuring adequate levels of required quality.

\subsection{Obtained Certificates}

The cement company "Ain Touta" obtained many certificates which are summarized in the following table:

Table (01). Obtained Certificates.

\begin{tabular}{lll}
\hline Systems & Certificate & Year \\
\hline Environment functioning system & ISO 14001 & 2004 \\
Health and safety at work functioning system & OHSAS 18001 & 2007 \\
Quality functioning system & ISO 9001 & 2008 \\
Health and safety at work functioning system & OHSAS 18001 & 2013 \\
\hline
\end{tabular}

\section{Field Study}

This part will be about how to test the study's tool to make sure of the extent of its sincerity and constancy. After, we move to highlight the statistical treatment methods used in the study and we conclude with displaying the results and testing the hypotheses.

\subsection{Research Methodology and Used Tools}

In this part, we will explain the method taken in the study with mention of the study's population, the time, space and human boundaries, and the tools used in the study.

\section{The Study's Method}

The method in the field study is the intended way to reach the underlined objectives, and it is the approach that the researcher can route to access to the declared objective; the nature of the research which highlights the relationship between the dimensions of intellectual capital and competitive capacities requires us to use the descriptor-analytical method to concrete the reality of the relationship between the study's variables and their indicators. The method is based on the data collection process and their analysis, explaining and obtaining generalizations. So, the function of the method is understanding and explaining, as well as description and analysis.

2. The study's Limits: the limits of the study are:

- Time framework: in fact, this study began in the second semester of 2014 with the distribution of questionnaires, unloading, tabulation and analysis of data.

- Space framework: This field research was conducted from the province of Batna.

3. The study's population: the study's population is composed from the total mass of workers at the General Direction of the Cement "Ain Touta". Considering that the General Direction is a part of the original cement company "Ain Touta" and because of the large number of workers that requires a lot of effort and time, the questionnaire was distributed to a sample of 35 workers at the direction representing the whole number of the direction. 35 questionnaires were distributed and only 20 were retired (recovery rate: $57 \%$ ).

4. Used Tools:

Questionnaire: the questionnaire is an important tool of data collection; it is a series of questions written in the form of a series of questions that must be easy and clear. Considering that the research population is workers, the form has been delivered by hand to most of them and we came back later to receive them. Before this, this questionnaire has been designed out of 24 questions according to Likert's scale (NOT COMPLETELY OK, COMPLETELY OK).

Questions were divided as follows:

- First class: concerns the personal data of the research community.

- Second class: intellectual capital dimensions.

- Third class: competitive capacities.

\subsection{Analysis of the Questionnaire's Results}

We will deal with how to test the study's tool to ensure its sincerity and constancy, then we will move to highlight the statistical treatment methods used in the study, and finally we conclude with displaying the results and testing hypotheses.

1. Study's Tool Testing (Questionnaire):

We will try to study the seeming and structural sincerity and constancy of the study's tool:

a. Study's tool sincerity: it means that the form should involve all of the elements that must be included in the analysis on one hand. On the other hand, its paragraphs and vocabulary must be clear so that they can be understood by the users. The study's tool sincerity has been confirmed by:

- The seeming sincerity of the tool: to see the extent of the tool seeming sincerity, it was presented to a group of expert and specialist professors; 
according to their opinions and suggestions, this questionnaire was drafted in its final form which was distributed to the researched sample.

- The constancy of the questionnaire: the constancy of the questionnaire is defined as "the extent of the ability of the tool to give similar results if applied under the same conditions and on the same subjects", we used in the study Cronbach's alpha way to calculate the constancy of standards using the statistical software package SPSS; the value of the correlation coefficient alpha ranges between (0-1). In order that the scale will be constant, the minimum value of the coefficient in this test should not be less than $(0,6)$. Alpha results, in our study, are shown in the following table:

Table (02). Results of the Study's tool Constancy Using Cronbach's Alpha.

\begin{tabular}{ll}
\hline Number of phrases & Degree of Cronbach's alpha coefficient \\
\hline 24 & 0,858 \\
\hline
\end{tabular}

Source: prepared by the researchers using the results of the questionnaire analysis and SPSS software outputs.

It is clear from the previous table that the value of Cronbach's alpha coefficient was $85.8 \%$, thus the analysis results based on this form are acceptable.

b. Description of the Study's Sample Characteristics: The following is a display of the obtained results relating to the study's sample characteristics according to the personal variables using the descriptive analysis presented by frequencies and percentages.

It is noted from table (03) what follows:

1. The distribution of the study's sample by sex: it is seen in the table (03) that the highest percentage in the category of sex is $(65 \%)$ recorded in males, while the percentage of females is $(35 \%)$.

2. The distribution of the study's sample by age: it is noted in the table (03) the high percentage of the two categories of age "30-40 years" and "40-50 years" $(30 \%)$, as we note that the lowest percentage is recorded at the category of "21-30 years," (15\%), while the ages category "50 years and more" recorded $(25 \%)$ of the total of the study's sample.

3. The distribution of the study's sample by marital status: it is seen in the table (03) that the highest percentage in terms of marital status is $(80 \%)$ to the category of married subjects, while the lowest percentage is in the category of divorced $(5 \%)$.

4. The distribution of the study's sample by academic qualification: it is seen in the table (03) that the university level achieves the highest percentage (70\%) which indicates that a large proportion of the sample holds academic qualifications- one of the positive indicators, then followed the higher studies level $(15 \%)$, the secondary one $(10 \%)$ and the middle level (5\%).

5. The distribution of the study's sample by experience in current job: we can note in the table (03) a high percentage of "10 years and more" of experience $(50 \%)$ which means that the organization has competences. We see also that the lowest percentage is recorded at "6-10 years" $(10 \%)$, while for the "less than 3 years" the percentage is $(25 \%)$, and at " $3-6$ years" $(15 \%)$.

Table (03). Distribution of the Sample's Subjects According to Personal Variables.

\begin{tabular}{|c|c|c|c|}
\hline Variable & & Frequencies & Percentages \% \\
\hline \multirow{2}{*}{ Sex } & Male & 13 & 65 \\
\hline & Female & 7 & 35 \\
\hline \multirow{4}{*}{ Age } & From 21-30 Y.O & 3 & 15 \\
\hline & From $30-40$ Y.O & 6 & 30 \\
\hline & From 40-50 Y.O & 6 & 30 \\
\hline & $50 \mathrm{Y} . \mathrm{O}$ and more & 5 & 25 \\
\hline \multirow{4}{*}{ Marital status } & Single & 3 & 15 \\
\hline & Married & 16 & 80 \\
\hline & Divorced & 1 & 5 \\
\hline & Widower & 0 & 0 \\
\hline \multirow{4}{*}{$\begin{array}{l}\text { Academic } \\
\text { qualification }\end{array}$} & Middle & 1 & 5 \\
\hline & Secondary & 2 & 10 \\
\hline & University & 14 & 70 \\
\hline & Higher studies & 3 & 15 \\
\hline \multirow{4}{*}{$\begin{array}{l}\text { Experience in } \\
\text { current job }\end{array}$} & Less than 3 years & 5 & 25 \\
\hline & From 3-6 years & 3 & 15 \\
\hline & From 6-10 years & 2 & 10 \\
\hline & 10 years and more & 10 & 50 \\
\hline
\end{tabular}

Source: prepared by the researchers using the results of the questionnaire analysis and SPSS software outputs.

\section{Descriptive Scales of the study's variables:}

Likert dual scale was used, then the extent $(2-1=1)$ was calculated and divided by the number of the scale's cells to get the correct length of the cell $(2 / 1=0.50)$. After, the value was added to the lowest value in the scale (the whole one) in order to determine the upper limit of this cell. Thus the length of the cells became as follows:

From (1 to 1.50$)$ represents very weak toward every phrase of the form.

From (1.51 to 2$)$ represents very high toward every phrase of the form.

- Descriptive standards of the independent variable: the following table represents the arithmetic averages and standard deviations of the independent variable: 
Table (04). Arithmetic Averages and Standard Deviations of the First Chapter Phrases.

\begin{tabular}{|c|c|c|c|c|}
\hline Phrases & Arithmetic average & Standard deviation & Classification & Degree \\
\hline $\begin{array}{l}\text { Workers have constantly full knowledge about all new related to the services } \\
\text { provided by the company }\end{array}$ & 1,70 & 0,470 & 3 & Very high \\
\hline The company's workers have high experience in the domain of their works & 1,85 & 0,366 & 1 & Very high \\
\hline $\begin{array}{l}\text { The direction's workers have the capacity to generate ideas and give quick } \\
\text { solutions to face work problems }\end{array}$ & 1,70 & 0,470 & 4 & Very high \\
\hline $\begin{array}{l}\text { Workers have creative and distinctive capacities in dealing with emergency } \\
\text { situations at work. }\end{array}$ & 1,60 & 0,503 & 5 & Very high \\
\hline $\begin{array}{l}\text { Spirit of cooperation between managers and workers in the direction is } \\
\text { available. }\end{array}$ & 1,80 & 0,410 & 2 & Very high \\
\hline Total & 1,73 & 0,313 & Very high & \\
\hline
\end{tabular}

Source: prepared by the researchers using the results of the questionnaire analysis and SPSS software outputs.

Table (04) shows that the general arithmetic average of all of the paragraphs of (human capital), which is located within the area of evaluation, is very high (1.73) and it is an acceptable value indicating a very high acceptance by the sample's subjects.

- Descriptive scales of the dependent variable: The following table represents the arithmetic averages and standard deviations of the dependent variable:

Table (05). Arithmetic Averages and Standard Deviations of the Second Chapter phrases.

\begin{tabular}{|c|c|c|c|c|}
\hline Phrases & Arithmetic average & Standard deviation & Classification & Degree \\
\hline $\begin{array}{l}\text { Information systems used in the direction provide to the decision- } \\
\text { makers the necessary information efficiently and quickly. }\end{array}$ & 1,80 & 0,410 & 2 & Very high \\
\hline $\begin{array}{l}\text { There is a continuous development of administrative processes in the } \\
\text { direction in a way that realizes distinctive performance in doing works. }\end{array}$ & 1,70 & 0,470 & 5 & Very high \\
\hline $\begin{array}{l}\text { Work policies and procedures ensure, at the company, the creation of } \\
\text { new and continuous knowledge. }\end{array}$ & 1,70 & 0,470 & 4 & Very high \\
\hline $\begin{array}{l}\text { The direction encourages scientific development of workers through } \\
\text { education and training programs offered to them. }\end{array}$ & 1,90 & 0,308 & 1 & Very high \\
\hline $\begin{array}{l}\text { The organizational structure of the direction provides high degree of } \\
\text { clarity in the nature of relationships between superiors and } \\
\text { subordinates. }\end{array}$ & 1,75 & 0,444 & 3 & Very high \\
\hline Total & 1,77 & 0,299 & Very high & \\
\hline
\end{tabular}

Source: prepared by the researchers using the results of the questionnaire analysis and SPSS software outputs.

Table (05) shows that the general arithmetic average of all of the paragraphs of (structural capital), which is located within the area of evaluation, is very high (1.77) and it is an acceptable value indicating a very high acceptance by the sample's subjects.

- Descriptive scales of the third chapter: the following table represents the arithmetic averages and standard deviations of the third chapter:

Table (06). Arithmetic averages and standard deviations of the third chapter phrases.

\begin{tabular}{|c|c|c|c|c|}
\hline Phrases & Arithmetic average & Standard deviation & Classification & Degree \\
\hline $\begin{array}{l}\text { The direction devotes adequate balance to provide distinctive } \\
\text { after-sale services to clients. }\end{array}$ & 1,30 & 0,470 & 3 & Very weak \\
\hline The direction devotes considerable time to choose suppliers. & 1,65 & 0,489 & 2 & Very high \\
\hline $\begin{array}{l}\text { The direction makes a range of strategic alliances with other } \\
\text { establishments to realize its works. }\end{array}$ & 1,70 & 0,470 & 1 & Very high \\
\hline Total & 1,55 & 0,363 & Very high & \\
\hline
\end{tabular}

Source: prepared by the researchers using the results of the questionnaire analysis and SPSS software outputs. Table (06) shows that the general arithmetic average of all of the paragraphs of the independent variable (relations capital), which is located within the area of evaluation, is very high (1.55) and it is an acceptable value indicating a very high acceptance by the sample's subjects due to the importance of the relations capital at the direction. We note that the arithmetic average of the first paragraph is $(1,30)$ and the standard deviation is $(0,470)$ and it is very weak within the second category of Likert's scale; it means that the direction does not devote adequate balance to provide distinctive after-sale services to clients. 
Table (07). Arithmetic averages and standard deviations of the second section phrases.

\begin{tabular}{|c|c|c|c|c|}
\hline Phrases & Arithmetic average & Standard deviation & Classification & Degree \\
\hline The centers providing services are attractive and comfortable for clients. & 1,65 & 0,489 & 8 & Very high \\
\hline $\begin{array}{l}\text { The direction's workers perform services to clients quickly, on time and } \\
\text { as required. }\end{array}$ & 1,75 & 0,444 & 7 & Very high \\
\hline $\begin{array}{l}\text { The direction reviews its various activities and operations and works to } \\
\text { cancel unnecessary and duplicated activities and operations. }\end{array}$ & 1,80 & 0,410 & 4 & Very high \\
\hline $\begin{array}{l}\text { The direction seeks to adopt all ways, methods and strategies to develop } \\
\text { the efficiency of its processes. }\end{array}$ & 1,90 & 0,308 & 2 & Very high \\
\hline $\begin{array}{l}\text { Information systems used at the direction contribute to reduce the costs of } \\
\text { operations and services. }\end{array}$ & 1,80 & 0,410 & 5 & Very high \\
\hline $\begin{array}{l}\text { The internal control range at the direction includes the examination and } \\
\text { evaluation of the efficiency and effectiveness of operations. }\end{array}$ & 1,90 & 0,308 & 3 & Very high \\
\hline $\begin{array}{l}\text { Information technology used in the direction helps the quick development } \\
\text { and the diversification of services provided to clients. }\end{array}$ & 1,80 & 0,410 & 6 & Very high \\
\hline $\begin{array}{l}\text { The direction adopts introducing and experimenting innovative ideas } \\
\text { generated by workers to face work problems }\end{array}$ & 1,40 & 0,503 & 11 & Very weak \\
\hline $\begin{array}{l}\text { The direction interests in developing the services provided to clients } \\
\text { according to what competitors offer. }\end{array}$ & 1,65 & 0,489 & 9 & Very high \\
\hline $\begin{array}{l}\text { The direction interests in opinions, suggestions and preferences of clients } \\
\text { to provide new services and make ameliorations to the provided services. }\end{array}$ & 1,55 & 0,510 & 10 & Very high \\
\hline The direction seriously seeks to apply domestic and international quality. & 2 & 0,000 & 1 & Very high \\
\hline Total & 1,75 & 0,210 & Very high & \\
\hline
\end{tabular}

Source: prepared by the researchers using the results of the questionnaire analysis and SPSS software outputs.

Table (07) shows that the general arithmetic average of all of the paragraphs of the independent variable (competitive capacities), which is located within the area of evaluation, is very high (1.75) and it is an acceptable value indicating a very high acceptance by the sample's subject due to the importance of competitive capacities at the direction. We note that the arithmetic average of the eighth paragraph is $(1,40)$ and the standard deviation is $(0,503)$ and it is very weak within the second category of Likert's scale; it means that the general direction does not adopt the introduction and experimentation of innovative ideas generated by workers to face work problems.

First: Testing the Principle Hypothesis

In order to test the principle hypothesis, we need to put two hypotheses: nothingness hypothesis and alternative hypothesis, considering that nothingness hypothesis is subject to test, that is to say it can be incorrect, which requires to put alternative hypothesis.

- Nothingness hypothesis H0: there is no relationship of statistical significance between the availability range of intellectual capital requirements and the development of competitive capacities the level of significance $a=$ 0.05 .

- Alternative hypothesis H1: there is a relationship of statistical significance between the availability range of intellectual capital requirements and the development of competitive capacities at the level of significance $a=$ 0.05 .

1. Analysis of Impact Relationship:

- To identify the existence range of an impact relationship of intellectual capital requirements on developing competitive capacities, and in order to test the model's ability to explanation, correlation coefficient $(\mathrm{R})$, determination coefficient $\left(\mathrm{R}^{2}\right)$ and modified determination coefficient $\left(\mathrm{R}^{-2}\right)$, which provides more accurate and correct explanation due to the presence of more than one independent variable, have been used. This is shown in the following table:

Table (08). Summary of the declination model of intellectual capital requirements impact on the development of competitive capacities.

\begin{tabular}{llll}
\hline correlation coefficient $(\mathbf{R})$ & Determination coefficient square $\left(\mathbf{R}^{2}\right)$ & Determination Coefficient $\left(\mathbf{R}^{-2}\right)$ & Standard error \\
\hline 0,610 & 0,373 & 0,338 & 0,171 \\
\hline
\end{tabular}

Source: prepared by the researchers using SPSS software results.

Table (09). Analysis of declination variance ANOVA.

\begin{tabular}{lllll}
\hline & Total of variance Square & Degrees of freedom & Variance average square & Value of the calculated (F) \\
Declination & 0.373 & 3 & 0.124 & 4.297 \\
Remainders & 0.463 & 16 & $/$ & 0.21 \\
Total & 0.836 & 19 & $/$ \\
\hline
\end{tabular}

Source: prepared by the researchers using the results SPSS software SPSS. 
Table (08) shows that:

- Correlation coefficient $(\mathrm{R})$ equals to $(0,610)$ and this means the existence of a medium-power direct relationship between intellectual capital requirements and the development of competitive capacities.

Table (09) shows that: The value of the test $(\mathrm{F})$ equals to $(2,75)$ and the calculated corresponding level of significance is (0.06), and it is not significant at the level (5\%) which means that the variable of intellectual capital requirements affects the competitive capacities development.

Based on the previous results of the statistical analysis

Alternative hypothesis $\mathrm{H} 1$, which states that there is a relationship of statistical significance between the
- Determination coefficient (R2) equals to $(0,373)$ and this means that intellectual capital requirements explain only $(37 \%)$ of the change in competitive capacities development, while the remainder percentage is attributed to other factors which are not studied.

availability range of intellectual capital requirements and the development of competitive capacities at the level of significance $a=0.05$, is accepted.

Second: Testing Partial Hypotheses

To test the first and second partial hypotheses, multiple declination and $(\mathrm{T})$ test have been adopted to test separately the significance of each parameter of the model, at the level of significance $\alpha=5 \%$. This is shown in the following table:

Table (10). Test of declination coefficients significance according to the statistical (T).

\begin{tabular}{lllllll}
\hline Variables & Declination coefficient (B) & Standard error & Standard declination & Test (T) & Level of significance & Statistical significance \\
\hline Constant & 0,847 & 0,274 & & 3,093 & 0,007 & \\
Human capital & 0,118 & 0,179 & 0,177 & 0,660 & 0,518 & Significant \\
Structural capital & 0,150 & 0,174 & 0,214 & 0,861 & 0,402 & Insignificant \\
Relations capital & 0,276 & 0,118 & 0,487 & 2,330 & 0,033 & Insignificant \\
\hline
\end{tabular}

Source: prepared by the researchers using SPSS software results.

In order to explain the results of the above table, it is necessary to give a precise detail about partial hypotheses to be tested, which will be displayed as follows:

2. The first partial hypothesis HA

- Nothingness hypothesis HA0: there is no relationship of statistical significance between human capital and the development of competitive capacities at the level of significance $a=0.05$.

- Alternative hypothesis HA1: there is a relationship of statistical significance between human capital and the development of competitive capacities at the level of significance $a=0.05$.

- It is shown in the table (10) that declination coefficient $(\mathrm{B})$ equals to $(0,118)$ which means that the relationship between human capital and the development of competitive capacities is direct; it is an insignificant at the level $(5 \%)$. The value of the test $(\mathrm{T})$ equals to $(0.660)$ and the corresponding significance level is (0.518), and it is insignificant at the level $(5 \%)$, which means that there is no impact relationship between human capital and the development of competitive capacities. Thus, we accept the nothingness hypothesis (HB0) which states that there is no impact relationship of statistical significance between human capital and the development of competitive capacities at the level of significance $a=0.05$.

3. The second partial hypothesis HB

- Nothingness hypothesis HB0: there is no relationship of statistical significance between structural capital and the development of competitive capacities at the level of significance $\mathrm{a}=0.05$.

- Alternative hypothesis HB1: there is a relationship of statistical significance between structural capital and the development of competitive capacities at the level of significance $a=0.05$.

- It is shown in the table (10) that declination coefficient (B) equals to $(0,150)$ which means that the relationship between structural capital and the development of competitive capacities is direct; it is insignificant at the level $(5 \%)$. The value of the $(\mathrm{T})$ test equals to $(0.861)$ and the corresponding significance level is (0.402); it is insignificant at the level $(5 \%)$, which means that there is no impact relationship between structural capital and the development of competitive capacities. Thus, we accept the nothingness hypothesis (HB0) which states that there is no impact relationship of statistical significance between structural capital and the development of competitive capacities at the level of significance $a=0.05$.

4. The third partial hypothesis $\mathrm{HC}$

- Nothingness hypothesis HC0: there is no relationship of statistical significance between relations capital and the development of competitive capacities at the level of significance $a=0.05$.

5. Alternative hypothesis $\mathrm{HC1}$ : there is a relationship of statistical significance between relations capital and the development of competitive capacities at the level of significance $a=0.05$.

- It is shown in the table (10) that declination coefficient (B) equals to $(0,270)$ which means that the relationship between relations capital and the development of competitive capacities is direct; it is significant at the level (5\%). The value of the(T) test equals to (2.330) and the corresponding significance level is (0.033); it is significant at the level (5\%), which means that there is an impact relationship 
between relations capital and the development of competitive capacities. Thus, we accept the alternative hypothesis ( $\mathrm{HC} 1)$ which states that there is an impact relationship of statistical significance between relations capital and the development of competitive capacities at the level of significance $a=$ 0.05 .

Third: Study's Results

1. Principle hypothesis: there is a relationship of statistical significance between the availability range of intellectual capital requirements and the development of competitive capacities at the level of significance $a=$ 0.05 , is a correct hypothesis.

2. The first secondary hypothesis: there is a relationship of statistical significance between the availability range of human capital requirements and the development of competitive capacities at the level of significance $\mathrm{a}=$ 0.05 , is an incorrect hypothesis.

3. The second secondary hypothesis: there is a relationship of statistical significance between the availability range of structural capital requirements and the development of competitive capacities at the level of significance $a=0.05$, is an incorrect hypothesis.

4. The third secondary hypothesis: there is a relationship of statistical significance between the availability range of relations capital requirements and the development of competitive capacities at the level of significance $a=$ 0.05 , is a correct hypothesis.

\section{Conclusion}

By projecting theoretical ideas and concepts on the practice, a set of results and suggestions have been reached:

First: Study's Results:

Through this study, we conclude to the following results:

1. There is a strong relationship between the availability of intellectual capital requirements and the development of competitive capacities at the direction.

2. There is no relationship between human capital and the development of competitive capacities.

3. There is no relationship between structural capital and the development of competitive capacities.

4. There is a relationship between relations capital and the development of competitive capacities.

\section{Second: Recommendations}

1. The direction should give great importance to human capital, in its various aspects of knowledge, exploit the available experiences and capacities and encourage the work by teams.

2. The organization should give more attention to structural capital to help workers to know the policies, programs and operations carried out by the organization.

3. Also, it should exploit its good relation with suppliers and clients and particularly develop it with clients by providing after-sale services.

4. The direction should adopt the introduction and experimentation of innovative ideas generated by workers to face sale problems.

\section{References}

[1] Barney, J. (2003), Gaining \& Sustaining Competitive Advantage, 2nd edition, Upper Saddle River, NJ: Prentice Hall.

[2] Bontis, N., Richards, D. \& Sernko, A. (2011), "Improving Service Delivery. Investigating The Role Of Information Sharing, Job Characteristics, And Employee Satisfaction", The learning organization, Vol.18, No. 3, pp. 239-250.

[3] Brooking, A. (1996), Intellectual Capital: Core Asset for the Third Millennium Enterprise, London, International Thomas business Press.

[4] Carmeli, A. \& A.Cohen, (1999), “Organizational Reputation as a Source of Sustainable Competitive Advantage and Above- Normal Performance", Available on line at http://www.pamij.com.

[5] Curado, C., Henriques, L. \& Bontis, N. (2011), "Intellectual capital disclosure payback", Management decision, Vol. 49, No.7, pp.1080-1098.

[6] Edvinsson, L. (1999), "Intellectual Capital of Nations for Future Wealth Creation", Journal of Human Resource Costing and Accounting, Vol. 4 Iss: 1, pp.22-30. http://dx.doi.org/10.1108/eb029051.

[7] Evans, and Collier, (2007), Operation Management an Integrated Goods and services, Approach, Thomson, South western, U.S.A international, studentedition,www.swlearing.com.

[8] Guthrie, J. (2001), "the Management, Measurement and Reporting of Intellectual Capital", Journal of Intellectual Capital, Vol. 2 Iss: 1, pp.27 - 41. http://dx.doi.org/10.1108/14691930110380473

[9] Hill, Charles \& Johns Jarret (2001), Strategy Management: Integrated Introduction.

[10] McElroy, M. W. (2002), "Social Innovation Capital”, Journal of International Capital, Vol. 3 Iss: 1, pp.30 - 39, http://dx.doi.org/10.1108/14691930210412827.

[11] Lumpkin Eisner, D. (2008), Strategic Management: Text and Cases, McGraw-Hill International Edition.

[12] McGee, J. E. \& Love, L. G. (1999), "Sources of Competitive Advantage for small independent retailers: Lessons from the neighborhood drugstores", association for small business \& entrepreneurship, Houston.

[13] Ngah, R. \& Abdul Razak, I. (2009), “The relationship of Intellectual Capital, Innovation and Organizational Performance: a Preliminary Study in Malaysian SMEs", International Journal of Management Innovation Systems. Vol. $1, \mathrm{~N} 1$.

[14] Porter, M. (1993), "Competitive Advantage of Nations", Harvard Business Review, Inter-edition.

[15] Stewart, A. Thomas (1997), Intellectual Capital: the New Wealth of Organization, Doubleday, New York.

[16] Williams, J.R. (1992), "How Sustainable Is Your Competitive Advantage?", California Management Review, Spring, Vol. 34, Issue. 3. 